ISSN 0258-7122

Bangladesh J. Agril. Res. 36(1) : 75-85, March 2011

\title{
EFFECT OF ZINC AND BORON ON YIELD AND YIELD CONTRIBUTING CHARACTERS OF MUNGBEAN IN LOW GANGES RIVER FLOODPLAIN SOIL AT MADARIPUR, BANGLADESH
}

\author{
M. A. QUDDUS ${ }^{1}$, M. H. RASHID ${ }^{2}$, M. A. HOSSAIN ${ }^{3}$ \\ AND H. M. NASER ${ }^{4}$
}

\begin{abstract}
An experiment was carried out in Calcareous Low Ganges River Floodplain Soil (AEZ 12) at Pulses Research Sub-Station (PRSS), Madaripur during Kharif I of 2008 and 2009.The objectives were to evaluate the effect of zinc (Zn) and boron (B) on the yield and yield contributing characters of mungbean (Vigna radiata L. Wilczek) and to find out the optimum dose of $\mathrm{Zn}$ and $\mathrm{B}$ for yield maximization. There were four levels of zinc $(0,0.75,1.5$, and $3.0 \mathrm{~kg} / \mathrm{ha}$ and boron (0, 0.5, 1.0, and $2 \mathrm{~kg} / \mathrm{ha}$ ) along with a blanket dose of $\mathrm{N}_{20} \mathrm{P}_{25} \mathrm{~K}_{35} \mathrm{~S}_{20}$ $\mathrm{kg} / \mathrm{ha}$. The experiment was laid out in RCBD with three replications. Results showed that the combination of $\mathrm{Zn}_{1.5} \mathrm{~B}_{1.0}$ produced significantly higher yield (3058 kg/ha) and (2631 kg/ha, in the year 2008 and 2009, respectively. The lowest yield (2173 kg/ha) and (1573 kg/ha, were found in control $\left(\mathrm{Zn}_{0} \mathrm{~B}_{0}\right)$ combination. The combined application of zinc and boron were observed superior to their single application in both the years. Therefore, the combination of $\mathrm{Zn}_{1.5} \mathrm{~B}_{1.0}$ might be considered as suitable dose for mungbean cultivation in Bangladesh. But from regression analysis, the optimum treatment combination was $\mathrm{Zn}_{1.87} \mathrm{~B}_{1.24} \mathrm{~kg} / \mathrm{ha}$ for Madaripur.
\end{abstract}

Keywords: Zinc, boron, mungbean, yield and yield contributing characters.

\section{Introduction}

Nutrient deficiency in soil is the key factor for poor productivity of pulses. The extent and magnitude of nutrient deficiency has aggravated in the recent past due to intensive agriculture and indiscriminate use of plant nutrients (Anonymous, 2009). Among pulses, mungbean (Vigna radiata L. Wilczek) is an important grain legume in Asia. It occupies an important position in this region. In Bangladesh, mungbean ranks second in acreage and production. It is an important source of protein and several essential micronutrients. It contains 24.5\% protein and 59.9\% carbohydrate. It also contains $75 \mathrm{mg}$ calcium, $8.5 \mathrm{mg}$ iron, and $49 \mathrm{mg} \beta$-carotene per 1 00g of split dal (Afzal et al., 2004). The foliage and stem are a good source of fodder for livestock. It synthesizes $\mathrm{N}$ in symbiosis with Rhizobia and enriches the soil. Total biomass of the soil is increased. It

\footnotetext{
${ }^{1 \& 2}$ Senior Scientific Officer, Pulses Research Sub-station, BARI, Madaripur, ${ }^{3}$ Senior Scientific Officer, Pulses Research Sub-station, BARI, Gazipur 1701 and ${ }^{4}$ Senior Scientific Officer, Soil Science Division, Bangladesh Agricultural Research Institute (BARI), Gazipur 1701, Bangladesh.
} 
improves the fertility status of soil through atmospheric $\mathrm{N}$ fixation and can fix $\mathrm{N}$ in soil by 63-342 kg/ha per season1 (Kaisher et al., 2010).

The soils of different parts of southern belt of Bangladesh are more or less deficient in boron and molybdenum as well as nitrogen fixing bacteria (Rhizobium sp.) which causes poor yield of mungbean. However, there is a great possibility to increase its production by cultivating HYV with balanced fertilization including micronutrient. Micronutrients play an important role in increasing yield of pulses and oilseed legumes through their effects on the plant itself and on the nitrogen fixing symbiotic process. Deficiencies of these nutrients have been very pronounced under multiple cropping systems due to excess removal by HYV of crops and hence their exogenous supplies are urgently required. Zinc and B deficiency is widespread in the country; much observed in wetland rice soils, light textured soils and calcareous soils (Jahiruddin et al., 1992; Rabman et al. 1993; Islam et al., 1997). Zinc is involved in auxin formation; activation of dehydrogenase enzymes; stabilization of ribosomal fractions (Obata et al., 1999). Boron is very important in cell division and in pod and seed formation (Vitosh et al., 1997). Rate of water adsorption and carbohydrate translocation restricted due to boron deficiency. Boron ranks third place among micronutrients, its concentration in seed and stem as well as its total amount after zinc (Robinson, 1973). Boron influences the absorption of N, P, K, and its deficiency changed the equilibrium of optimum of those three macronutrients. Inadequate supply of B decreased the economic yield of legume (Raj, 1985). The $\mathrm{N}$ and $\mathrm{B}$ concentrations of grain for mungbean were markedly influenced by B treatment indicating that the B had a positive role on protein synthesis. lqtidar and Rahman (1984) found that essential amino acid increased with increasing B supply. The critical level of boron with reference to crops in general was reported to a range from 0.3 to $0.8 \mathrm{ppm}$ depending on soil types (Shorrocks, 1984). Therefore, applications of micronutrients in addition to essential major elements have gained practical significance. The present study was, therefore, undertaken (i) to evaluate the response of $\mathrm{Zn}$ and B on the yield and yield contributing characters of mungbean, and (ii) to find out a suitable dose of $\mathrm{Zn}$ and $\mathrm{B}$ for the maximization of mungbean yield.

\section{Materials and Method}

A field experiment was conducted in Calcareous Low Ganges River Floodplain Soil (AEZ 12) at Pulses Research Sub-Station (PRSS), Madaripur during KharifI of 2008 and 2009. There were 16 treatment combinations comprising four levels each of zinc $(0,0.75,1.5$, and $3.0 \mathrm{~kg} / \mathrm{ha}$ and boron $(0,0.5,1.0$, and 2 $\mathrm{kg} / \mathrm{ha}$ ) along with a recommended fertilizer $\mathrm{N}_{20} \mathrm{P}_{25} \mathrm{~K}_{35} \mathrm{~S}_{20} \mathrm{~kg} / \mathrm{ha}$ as per soil test based (BARC, 2005). The treatments were arranged as follows: $T_{1}=Z_{0} B_{0} . T_{2}=$ $Z_{0} B_{0.5} . T_{3}=Z_{0} B_{1.0} . T_{4}=Z_{0} B_{2.0} . T_{5}=Z_{0.75} B_{0} . T_{6}=Z_{0.75} B_{0.5} T_{7}=Z_{0.75} B_{1.0} . T_{8}=$ 
$\mathrm{Zn}_{0.75} \mathrm{~B}_{2.0}, \mathrm{~T}_{9}=\mathrm{Zn}_{1.5} \mathrm{~B}_{0} . \mathrm{T}_{10}=\mathrm{Zn}_{1.5} \mathrm{~B}_{0} . \mathrm{T}_{11}=\mathrm{Zn}_{1.5} \mathrm{~B}_{1.0} . \mathrm{T}_{12}=\mathrm{Zn}_{1.5} \mathrm{~B}_{2.0} . \mathrm{T}_{13}=\mathrm{Zn}_{3.0} \mathrm{~B}_{0}$. $\mathrm{T}_{14}=\mathrm{Zn}_{3.0} \mathrm{~B}_{0.5}, \mathrm{~T}_{15}=\mathrm{Zn}_{3.0} \mathrm{~B}_{1.0}$. and $\mathrm{T}_{16}=\mathrm{Zn}_{3.0} \mathrm{~B}_{2.0}$, Before setting the experiments, initial soil samples were collected from the experimental field from 0-15 cm depth and the collected samples were analyzed for chemical properties using standard procedures in the laboratory. The experiment was laid out in a randomized complete block design with three replications. The unit plot size was $4 \mathrm{~m} 3 \mathrm{~m}$. The variety was BARI Mung-6. Blanket dose of fertilizers were applied at the time of final land preparation. Zinc and B were applied as zinc sulphate and boric acid, respectively, in the respective treatments plot during final land preparation. Seeds were sown @ $30 \mathrm{~kg} / \mathrm{ha}$ with a spacing of $40 \mathrm{~cm}$ x $10 \mathrm{~cm}$ on 21 February 2008 and on 26 February 2009. Two weedings were done at 20 and 35 days after sowing (DAS). The diseases and insects were controlled properly. Harvesting was started from 20 April to 27 May for 2008 and 25 April to 20 May for 2009. Yield contributing characters were recorded from 10 randomly selected plants from each plot. Yield ( $\mathrm{kg} / \mathrm{ha}$ ) was recorded from the whole plot technique. Postharvest soil samples were also collected from 0-15 cm depth and were analyzed for chemical properties using the standard procedures in the laboratory. The data were then statistically analyzed by using MSTAT.

\section{Results and Discussion}

\section{Effect of zinc}

Mungbean yield was significantly increased due to the application of zinc for both the years 2008 and 2009 (Table 1). Highest seed yield (2865 kg/ha) was obtained from $\mathrm{T}_{3}$ treatment (1.5 kg Zn/ha, which was statistically similar with $\mathrm{T}_{2}$ and $\mathrm{T}_{4}$ but significantly higher than $\mathrm{T}_{1}$ (Control). Similar trend was also observed in 2009. Treatment $T_{3}$ though yielded significantly higher than control but statistically no variation was observed with other treatments (Table 1). For both the years, lowest yield was with the control i.e. $\mathrm{T}_{1}$ treatment. From the Table 1, it was observed that the yield increased gradually with the increase of $\mathrm{Zn}$ level up to $1.5 \mathrm{~kg} / \mathrm{ha}$ and decreased with Zn level $3.00 \mathrm{~kg} / \mathrm{ha}$ for both the years. Similar trend was also observed by several authors (Ryan and El-Moneim, 2007). No significant variation was observed in case of 100 -seed weight Seed weight increased with the increase of $\mathrm{Zn}$ level upto $1.5 \mathrm{~kg} / \mathrm{ha}$ and then decreased with increased level of $\mathrm{Zn}(3.00 \mathrm{~kg} / \mathrm{ha}$ ) for both the years (Table 1). Except plant height, no other yield contributing characters showed significant variation due to different levels of $\mathrm{Zn}$ application. The highest plant height $47.8 \mathrm{~cm}$ and $44.0 \mathrm{~cm}$ were recorded with Zn level $1.5 \mathrm{~kg} / \mathrm{ha}$ in the year of 2008 and 2009, respectively, which were statistically identical with $T_{4}$ treatment $(3.0 \mathrm{~kg} \mathrm{Zn} / \mathrm{ha}$ ) for both the years, but statistically significant to others (Table 2). 
Table 1. Mean effect of zinc on 100-seed weight (g) and yield (kg/ha) of mungbean at on-station, Madaripur during 2008 and 2009.

\begin{tabular}{l|c|c|c|c|c|c|c}
\hline \multirow{2}{*}{$\begin{array}{c}\text { Levels of } \\
\text { Zinc (kg/ha) }\end{array}$} & \multicolumn{3}{|c|}{100 seed weight (g) } & \multicolumn{3}{c|}{ Yield (kg/ha) } & \multirow{2}{*}{$\begin{array}{c}\text { (\%) Yield } \\
\text { increased } \\
\text { over control }\end{array}$} \\
\cline { 2 - 7 } & 2008 & 2009 & Average & 2008 & 2009 & Average & - \\
\hline 0 & 5.85 & 5.20 & 5.53 & $2247 \mathrm{~b}$ & $1896 \mathrm{~b}$ & 2072 & 17.3 \\
0.75 & 5.95 & 5.39 & 5.67 & $2737 \mathrm{a}$ & $2124 \mathrm{ab}$ & 2431 & 24.7 \\
1.50 & 6.01 & 5.58 & 5.80 & $2865 \mathrm{a}$ & $2303 \mathrm{a}$ & 2584 & 16.7 \\
3.00 & 5.94 & 5.36 & 5.65 & $2686 \mathrm{a}$ & $2147 \mathrm{ab}$ & 2417 & - \\
\hline CV (\%) & 1.84 & 4.77 & - & 4.27 & 8.14 & - & - \\
\hline
\end{tabular}

Values within a column having same letter(s) do not differ significantly $(\mathrm{p}=0.05)$

Table 2. Mean effect of zinc on plant height $(\mathrm{cm})$, no. of pods per plant and no. of seeds per pod of mungbean at on-station, Madaripur during 2008 and 2009.

\begin{tabular}{l|c|c|c|c|c|c|c|c|c}
\hline \multirow{2}{*}{$\begin{array}{c}\text { Levels of } \\
\text { Zinc (kg/ha) }\end{array}$} & \multicolumn{3}{|c|}{ Plant height (cm) } & \multicolumn{3}{c|}{ No. of Pods/plant } & \multicolumn{3}{c}{ No. of seeds/ pod } \\
\cline { 2 - 11 } & 2008 & 2009 & Average & 2008 & 2009 & Average & 2008 & 2009 & Average \\
\hline 0 & $46.5 \mathrm{~b}$ & $41.2 \mathrm{~b}$ & 43.9 & 28.0 & 28.9 & 28.5 & 10.4 & 8.23 & 9.29 \\
0.75 & $46.6 \mathrm{~b}$ & $42.8 \mathrm{ab}$ & 44.7 & 28.2 & 30.5 & 29.3 & 10.4 & 8.33 & 9.34 \\
1.50 & $47.8 \mathrm{a}$ & $44.0 \mathrm{a}$ & 45.9 & 28.8 & 32.6 & 30.7 & 10.5 & 8.64 & 9.57 \\
3.00 & $46.9 \mathrm{ab}$ & $43 . \mathrm{Ia}$ & 45.0 & 28.3 & 29.5 & 28.9 & 10.4 & 8.45 & 9.43 \\
\hline $\mathrm{CV}(\%)$ & 1.10 & 2.32 & - & 7.51 & 11.43 & - & 6.40 & 5.98 & - \\
\hline
\end{tabular}

Values within a column having same letter(s) do not differ significantly $(\mathrm{p}=0.05)$

\section{Effect of boron}

No significant variation was observed in mungbean grain yield due to the application of boron in the year 2008, but in 2009 significant variation was observed (Table 3). Seed yield ranged from 2581-2690 kg/ha in the year 2008 where highest (2690 kg/ha with $\mathrm{T}_{3}$ and lowest (2581 kg/ha with $\mathrm{T}_{1}$ treatment. In the year 2009, the highest seed yield (2277 kg/ha) at $1.0 \mathrm{~kg} \mathrm{~B} / \mathrm{ha}\left(\mathrm{T}_{3}\right)$, which was statistically identical with $\left(\mathrm{T}_{4}\right.$ and $\left.\mathrm{T}_{2}\right) 0.50$ and $2.00 \mathrm{~kg} \mathrm{~B} / \mathrm{ha}$, but statistically significant over control $\left(\mathrm{T}_{1}\right)$. Verma and Mishra (1999) reported that the boron application has positive effect on mungbean yield. Similar trend was also reported by Ashraf (2007). Yield contributing character like 100-seed weight showed no significant effect due to boron application (Table 3). Average 100seed weight, highest (5.79 g) was with $\mathrm{T}_{3}$ and lowest (5.57 g) with $\mathrm{T}_{1}$ (control). Plant height showed significant variation due to different levels of $\mathrm{B}$ application in 2008, but effect was insignificant in 2009 (Table 4). The highest average plant height $(45.49 \mathrm{~cm})$ was recorded with $\mathrm{T}_{3}(1.00 \mathrm{~kg} \mathrm{~B} / \mathrm{ha}$ and the lowest $(44.44 \mathrm{~cm})$ was found with control $\left(\mathrm{T}_{1}\right)$ (Table 4$)$. Other characters, such as number of pods 
per plant and number of seeds per pod showed no significant variation due to the application of different levels of B in both the years (Table 4). Verma and Mishra (1999) reported the similar trend but different with Anonymous (2000).

Table 3. Mean effect of boron on 100-seed weight $(\mathrm{g})$ and yield $(\mathrm{kg} / \mathrm{ha})$ of mungbean at on-station, Madaripur during 2008 and 2009.

\begin{tabular}{l|ccc|c|c|c|c}
\hline \multirow{2}{*}{$\begin{array}{c}\text { Levels of } \\
\text { Zinc (kg/ha) }\end{array}$} & \multicolumn{3}{|c|}{ 100-seed weight (g) } & \multicolumn{3}{c|}{ Yield (kg/ha) } & \multirow{2}{*}{$\begin{array}{c}\text { (\%) Yield } \\
\text { increased }\end{array}$} \\
\hline 0 & 2008 & 2009 & Average & 2008 & 2009 & Average & \\
\hline 0.50 & 5.90 & 5.23 & 5.57 & 2581 & $1902 \mathrm{~b}$ & 2250 & - \\
1.00 & 5.91 & 5.35 & 5.63 & 2629 & $2142 \mathrm{ab}$ & 2386 & 6.04 \\
2.00 & 5.98 & 5.59 & 5.79 & 2690 & $2277 \mathrm{a}$ & 2484 & 10.4 \\
\hline CV (\%) & 5.97 & 5.35 & 5.66 & 2635 & $2149 \mathrm{ab}$ & 2392 & 6.31 \\
\hline
\end{tabular}

Values within a column having same letter(s) do not differ significantly ( $\mathrm{p}=0.05)$.

Table 4. Mean effect of boron on plant height $(\mathrm{cm})$, no. of pods per plant and no. of seeds per pod of mungbean at on-station, Madaripur during 2008 and 2009.

\begin{tabular}{|c|c|c|c|c|c|c|c|c|c|}
\hline \multirow{2}{*}{$\begin{array}{c}\text { Levels of } \\
\text { boron } \\
\text { (kg/ha) }\end{array}$} & \multicolumn{3}{|c|}{ Plant height (cm) } & \multicolumn{3}{|c|}{ No. of pods/plant } & \multicolumn{3}{|c|}{ No. of seeds/pod } \\
\hline & 2008 & 2009 & Average & 2008 & 2009 & Average & 2008 & 2009 & Average \\
\hline 0 & $46.4 \mathrm{~b}$ & 42.4 & 44.4 & 27.4 & 27.0 & 27.2 & 10.1 & 8.03 & 9.08 \\
\hline 0.50 & 46.8ab & 42.5 & 44.6 & 28.0 & 29.8 & 28.9 & 10.4 & 8.42 & 9.42 \\
\hline 1.00 & $47.7 \mathrm{a}$ & 43.3 & 45.5 & 28.4 & 32.0 & 30.2 & 10.6 & 8.77 & 9.68 \\
\hline 2.00 & $47.0 \mathrm{ab}$ & 43.1 & 45.1 & 28.3 & 30.0 & 29.1 & 10.5 & 8.45 & 9.48 \\
\hline CV (\%) & 1.10 & 2.32 & - & 7.51 & 11.43 & - & 6.40 & 5.98 & - \\
\hline
\end{tabular}

Values within a column having same letter(s) do not differ significantly ( $\mathrm{p}=0.05)$

\section{Interaction effect of zinc and boron}

The interaction effect between $\mathrm{Zn}$ and $\mathrm{B}$ on the yield cf mungbean was found statistically significant for both the years (2008 and 2009). The highest yield (3058 and $2631 \mathrm{~kg} / \mathrm{ha}$ ) was obtained from $\mathrm{T}_{11}\left(\mathrm{Zn}_{1.5} \mathrm{~B}_{1.0}\right)$ treatment and the lowest (2173 and $1573 \mathrm{~kg} / \mathrm{ha}$ ) from $\mathrm{T}_{1}\left(\mathrm{Zn}_{0} \mathrm{~B}_{0}\right)$ for 2008 and 2009, respectively (Table 5). In the year 2008, Treatment $T_{1}$ yielded highest, which was statistically different from the treatments where no $\mathrm{Zn}$ was applied. On the other hand, no significant variation was observed with different levels of Zn. In the growing season 2009, similar trend was also observed (Table 5). However, mean yield ranged from 1873 to $2862 \mathrm{~kg} / \mathrm{ha}$, where highest was with $\mathrm{T}_{11}$ and lowest was with $\mathrm{T}_{1}$ treatment. Yield increased over control ranged from 9.88 to $52.80 \%$ (Table 5). 
The combined application of $\mathrm{Zn}$ and $\mathrm{B}$ showed significant effect on munbean yield than the single application of $\mathrm{Zn}$ and B. Sakal et al. (1986) observed the similar trend. Other yield contributing components like 100-seed weight, plant height, number of pods per p1ant and number of seeds per pod were significantly influenced due to the combined application of $\mathrm{Zn}$ and B except number of seeds per pod in the year 2008 (Table 5). Abdo (2001) reported the same with foliar spray of $\mathrm{Zn}$ and B.

Table 5. 100-seed weight (g) and yield (kg/ha) of mungbean as influenced by Zn and B fertilization at on-station, Madaripur during 2008 and 2009.

\begin{tabular}{|c|c|c|c|c|c|c|c|}
\hline \multirow{2}{*}{$\begin{array}{l}\text { Levels of } \mathrm{Zn} \\
\text { and B } \\
\text { fertilization } \\
\text { (kg/ha) }\end{array}$} & \multicolumn{3}{|c|}{ 100-seed weight (g) } & \multicolumn{3}{|c|}{ Yield (kg/ha) } & \multirow{2}{*}{$\begin{array}{c}\text { (\%) yield } \\
\text { increased } \\
\text { over } \\
\text { control }\end{array}$} \\
\hline & 2008 & 2009 & Average & 2008 & 2009 & Average & \\
\hline $\mathrm{T}_{1}=\mathrm{Zn}_{0} \mathrm{~B}_{0}$ & $5.65 \mathrm{~g}$ & $4.92 d$ & 5.29 & 2173d & $1573 f$ & 1873 & - \\
\hline $\mathrm{T}_{2}=\mathrm{Zn}_{0} \mathrm{~B}_{0.5}$ & $5.73 f g$ & $5.22 \mathrm{bcd}$ & 5.48 & $2245 c d$ & 1871e & 2058 & 9.88 \\
\hline $\mathrm{T}_{3}=\mathrm{Zn}_{0} \mathrm{~B}_{1.0}$ & 5.97cde & $5.42 \mathrm{a}-\mathrm{d}$ & 5.69 & 2254cd & 2143b-e & 2198 & 17.35 \\
\hline $\mathrm{T}_{4}=\mathrm{Zn}_{0} \mathrm{~B}_{2.0}$ & $6.03 \mathrm{~cd}$ & 5.23bcd & 5.63 & 2317bcd & 1995cde & 2156 & 15.11 \\
\hline $\mathrm{T}_{5}=\mathrm{Zn}_{0.75} \mathrm{~B}_{0}$ & $5.93 c-f$ & 5.36a-d & 5.64 & 2613a-d & 1978cde & 2295 & 22.53 \\
\hline $\mathrm{T}_{6}=\mathrm{Zn}_{0.75} \mathrm{~B}_{0.5}$ & 6.00cde & 5.44abc & 5.72 & 2785ab & 2217bcd & 2501 & 33.53 \\
\hline $\mathrm{T}_{7}=\mathrm{Zn}_{0.75} \mathrm{~B}_{1.0}$ & $5.83 \mathrm{~d}-\mathrm{g}$ & 5.59abc & 5.71 & 2763ab & 2217bcd & 2490 & 32.94 \\
\hline $\mathrm{T}_{8}=\mathrm{Zn}_{0.75} \mathrm{~B}_{2.0}$ & 5.87def & 5.17cd & 5.52 & 2787ab & 2083cde & 2435 & 30.01 \\
\hline $\mathrm{T}_{9}=\mathrm{Zn}_{1.5} \mathrm{~B}_{0}$ & $5.83 \mathrm{~d}-\mathrm{g}$ & 5.47abc & 5.65 & 2793ab & 1922de & 2358 & 26.43 \\
\hline $\mathrm{T}_{10}=\mathrm{Zn}_{1.5} \mathrm{~B}_{0.5}$ & $5.90 c-f$ & 5.35a-d & 5.63 & $2814 a$ & 2193b-e & 2504 & 33.10 \\
\hline $\mathrm{T}_{11}=\mathrm{Zn}_{1.5} \mathrm{~B}_{1.0}$ & 6.33a & $5.77 \mathrm{a}$ & 6.05 & $3058 a$ & 2631a & 2862 & 52.80 \\
\hline $\mathrm{T}_{12}=\mathrm{Zn}_{1.5} \mathrm{~B}_{2.0}$ & 6.23ab & $5.72 \mathrm{ab}$ & 5.97 & $2794 a$ & 2467ab & 2630 & 40.42 \\
\hline $\mathrm{T}_{13}=\mathrm{Zn}_{3.0} \mathrm{~B}_{0}$ & $6.10 \mathrm{bc}$ & $5.18 \mathrm{~cd}$ & 5.64 & 2726ab & 2134cde & 2430 & 29.74 \\
\hline $\mathrm{T}_{14}=\mathrm{Zn}_{3.0} \mathrm{~B}_{0.5}$ & 6.00cde & 5.38a-d & 5.69 & 2691abc & $2285 b c$ & 2488 & 32.84 \\
\hline $\mathrm{T}_{15}=\mathrm{Zn}_{3.0} \mathrm{~B}_{1.0}$ & 5.87def & 5.S7abc & 5.72 & 2730ab & 2280bc & 2505 & 33.74 \\
\hline $\mathrm{T}_{16}=\mathrm{Zn}_{3.0} \mathrm{~B}_{2.0}$ & 5.80efg & 5.30a-d & 5.55 & 2596a-d & 1887de & 2241 & 19.65 \\
\hline CV (\%) & 1.84 & 4.77 & - & 4.27 & 8.14 & - & - \\
\hline
\end{tabular}

Values within a column having same letter(s) do not differ significantly ( $\mathrm{p}=0.05$ )

Blanket dose : $\mathrm{N}_{20} \mathrm{P}_{25} \mathrm{~K}_{35} \mathrm{~S}_{20} \mathrm{~kg} / \mathrm{ha}$.

\section{Soil fertility status}

Initially the soil $\mathrm{pH}$ was 7.0. But after completion of two years' trial, the soil $\mathrm{pH}$ slightly increased in all treatments might be due to the incorporation of 
mungbean stover in soil (Table 7). The nutrient status both for macro and micro was influenced by stover incorporation. The amount of organic matter was highest $11.55 \%$ with treatment $\mathrm{T}_{11}$ and lowest was with $\mathrm{T}_{1}$ treatment. In most of the cases, the content of macro and micro nutrients were found higher with $\mathrm{T}_{11}$ treatment and lowest with $\mathrm{T}_{1}$ treatment (Table 7). Ahiawat and Srivastava (1997) observed that the incorporation of mungbean stover in soil after picking of pods resulted in an economy of about $23 \mathrm{~kg} \mathrm{~N} / \mathrm{ha}$ in succeeding crop. Rao and Bhardwaj (1980) found that the pulses receiving optimum fertilizer, especially $\mathrm{P}$ had more pronounced residual effect both for $\mathrm{N}$ and $\mathrm{P}$ in succeeding cereals.

Table 6. Plant height $(\mathrm{cm})$, no. of pods per plant and no. of seeds per pod of mungbean as influenced by $\mathrm{Zn}$ and $\mathrm{B}$ fertilization at on-station, Madaripur during 2008 and 2009.

\begin{tabular}{|c|c|c|c|c|c|c|c|c|c|}
\hline \multirow{2}{*}{$\begin{array}{l}\text { Levels of Zn } \\
\text { and B } \\
\text { fertilization } \\
\text { (kg/ha) }\end{array}$} & \multicolumn{3}{|c|}{ Plant height (cm) } & \multicolumn{3}{|c|}{ No. of pods/plant } & \multicolumn{3}{|c|}{ No. of seeds/pod } \\
\hline & 2008 & 2009 & Average & 2008 & 2009 & Average & 2008 & 2009 & Average \\
\hline $\mathrm{T}_{1}=\mathrm{Zn}_{0} \mathrm{~B}_{0}$ & $45.2 \mathrm{e}$ & $39.5 f$ & 42.3 & $25.3 c$ & 24.Ic & 25.4 & 9.5 & $7.62 c$ & 8.56 \\
\hline $\mathrm{T}_{2}=\mathrm{Zn}_{0} \mathrm{~B}_{0.5}$ & $46.9 c$ & $40.6 \mathrm{ef}$ & 43.8 & 27.8abc & 28.8abc & 28.3 & 10.2 & 8.35abc & 9.27 \\
\hline $\mathrm{T}_{3}=\mathrm{Zn}_{0} \mathrm{~B}_{1.0}$ & 46.6cd & 42.8bcd & 44.7 & 29.4abc & 31.3ab & 30.4 & 10.3 & 8.40abc & 9.35 \\
\hline $\mathrm{T}_{4}=\mathrm{Zn}_{0} \mathrm{~B}_{2.0}$ & $47.2 \mathrm{bc}$ & 42.lcde & 44.6 & 28.4abc & $31.4 \mathrm{ab}$ & 29.9 & 10.4 & 8.42abc & 9.41 \\
\hline $\mathrm{T}_{5}=\mathrm{Zn}_{0.75} \mathrm{~B}_{0}$ & $46.4 \mathrm{~cd}$ & 42.5bcd & 44.5 & 29.7ab & 28.8abc & 29.2 & 10.0 & $7.85 \mathrm{bc}$ & 8.92 \\
\hline $\mathrm{T}_{6}=\mathrm{Zn}_{0.75} \mathrm{~B}_{0.5}$ & 45.9de & 42.6bcd & 44.2 & 27.3bc & $32.0 \mathrm{ab}$ & 28.6 & 10.2 & 8.40abc & 9.30 \\
\hline $\mathrm{T}_{7}=\mathrm{Zn}_{0.75} \mathrm{~B}_{1.0}$ & $46.9 c$ & 43.3a-d & 45.1 & $27.4 \mathrm{bc}$ & 27.6bc & 27.5 & 10.1 & 8.5labc & 9.30 \\
\hline $\mathrm{T}_{8}=\mathrm{Zn}_{0.75} \mathrm{~B}_{2.0}$ & $47.2 \mathrm{bc}$ & 43.9abc & 45.6 & $30.2 \mathrm{ab}$ & 34.2ab & 32.2 & 10.2 & 8.37abc & 9.28 \\
\hline $\mathrm{T}_{9}=\mathrm{Zn}_{1.5} \mathrm{~B}_{0}$ & $46.8 \mathrm{~cd}$ & 43.3a-d & 45.0 & 27.Sbc & $27.5 b c$ & 27.5 & 10.4 & 8.47abc & 9.43 \\
\hline $\mathrm{T}_{10}=\mathrm{Zn}_{1.5} \mathrm{~B}_{0.5}$ & 47.3bc & 43.9abc & 45.6 & 28.Iabc & 30.9ab & 29.5 & 10.6 & 8.05abc & 9.32 \\
\hline $\mathrm{T}_{11}=\mathrm{Zn}_{1.5} \mathrm{~B}_{1.0}$ & 49.3a & $44.7 \mathrm{a}$ & 47.0 & $31.8 a$ & $35.5 a$ & 33.6 & 10.9 & $8.90 \mathrm{a}$ & 9.90 \\
\hline $\mathrm{T}_{12}=\mathrm{Zn}_{1.5} \mathrm{~B}_{2.0}$ & $47.9 \mathrm{~b}$ & $44.0 \mathrm{ab}$ & 46.0 & 28.7abc & $34.7 \mathrm{a}$ & 31.7 & 10.7 & 8.8lab & 9.75 \\
\hline $\mathrm{T}_{13}=\mathrm{Zn}_{3.0} \mathrm{~B}_{0}$ & $47.2 \mathrm{bc}$ & 43.5a-d & 45.3 & 27.7abc & 28.9abc & 28.4 & 10.5 & $8.20 \mathrm{abc}$ & 9.35 \\
\hline $\mathrm{T}_{14}=\mathrm{Zn}_{3.0} \mathrm{~B}_{0.5}$ & $46.9 \mathrm{bc}$ & 43.la-d & 45.0 & 28.5abc & $27.7 \mathrm{bc}$ & 28.1 & 10.6 & $8.68 \mathrm{ab}$ & 9.64 \\
\hline $\mathrm{T}_{15}=\mathrm{Zn}_{3.0} \mathrm{~B}_{1.0}$ & $46.6 \mathrm{~cd}$ & 43.0a-d & 44.8 & 28.2abc & $32.4 \mathrm{ab}$ & 30.3 & 10.5 & 8.77ab & 9.63 \\
\hline $\mathrm{T}_{16}=\mathrm{Zn}_{3.0} \mathrm{~B}_{2.0}$ & 47.Ibc & 41.6de & 44.4 & 27.8abc & $30.28 \mathrm{abc}$ & 29.0 & 10.3 & $8.70 \mathrm{ab}$ & 9.50 \\
\hline CV (\%) & 1.10 & 2.32 & - & 7.51 & 11.43 & - & 6.40 & 5.98 & - \\
\hline
\end{tabular}

Values within a column having same letter(s) do not differ significantly ( $\mathrm{p}=0.05$ )

Blanket dose: $\mathrm{N}_{20} \mathrm{P}_{25} \mathrm{~K}_{35} \mathrm{~S}_{20} \mathrm{~kg} / \mathrm{ha}$.

Regression analysis showed positive and quadratic response for mean yield and applied Zn. (Fig. 1). The optimum dose of Zn was calculated from the quadratic 
response function and was $1.87 \mathrm{~kg} / \mathrm{ha}$ (Table 8). For optimum dose, the maximum seed yield (2613 kg/ha could be expected for Madaripur area (Table 8). However, the optimum economic dose of $\mathrm{Zn}$ was $1.84 \mathrm{~kg} / \mathrm{ha}$. The use efficiency showed that each $1 \mathrm{~kg} \mathrm{Zn}$ could produce $287 \mathrm{~kg} / \mathrm{ha}$ of seed yield. Beyond the optimum dose, $1 \mathrm{~kg} / \mathrm{ha}$ excess $\mathrm{Zn}$ was applied, then a risk of loosing $154 \mathrm{~kg} / \mathrm{ha}$ of seed yield was noted (Table 8).

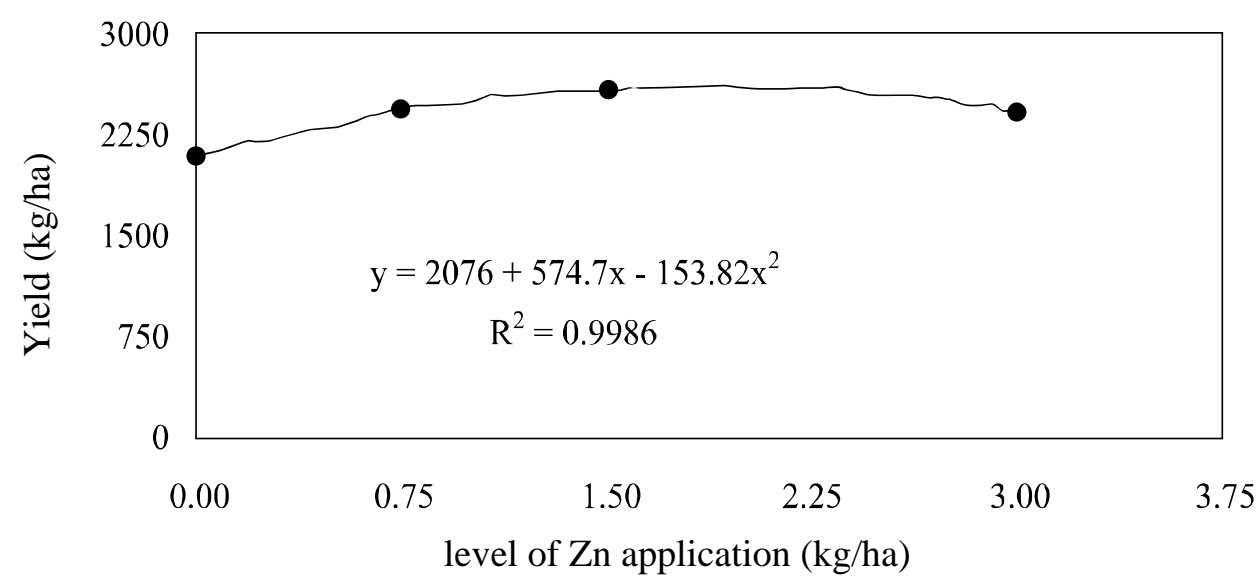

Fig. 1. Response of mungbean to Zn fertilization.

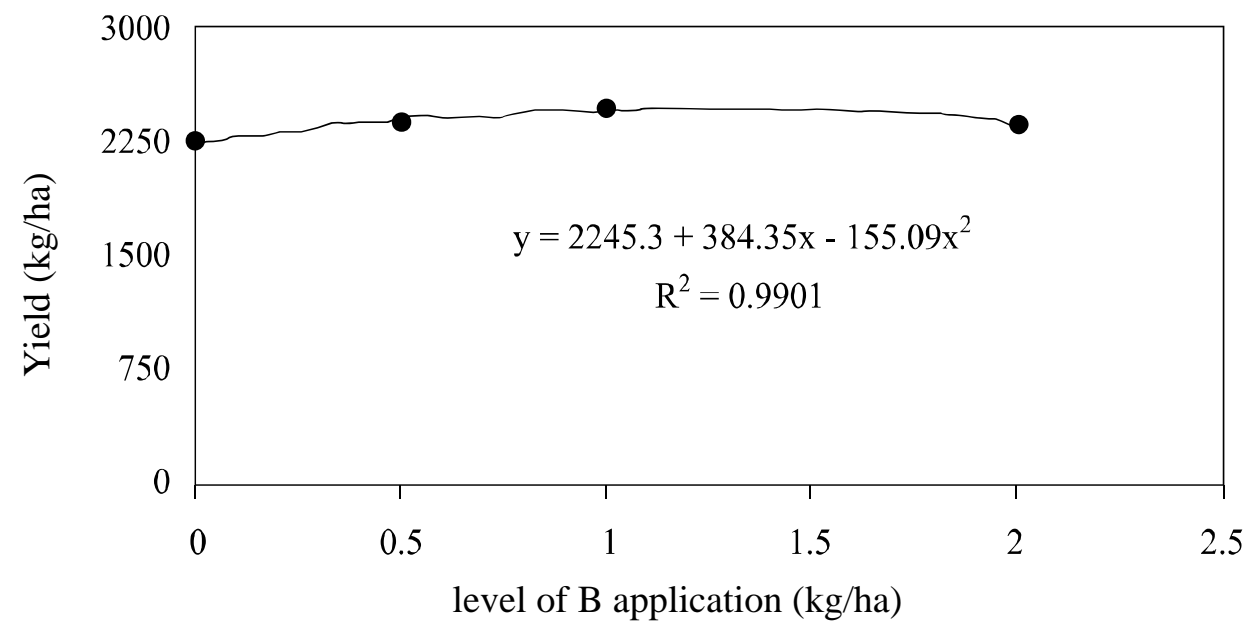

Fig. 2. Response of mungbean to B fertilization 
Table 7. Fertility status of initial and post harvest soil.

\begin{tabular}{|c|c|c|c|c|c|c|c|c|c|c|c|}
\hline \multirow[b]{2}{*}{ Treatment } & \multirow[b]{2}{*}{$\mathrm{pH}$} & $\mathrm{OM}$ & Total & $\mathrm{Ca}$ & Mg & $\mathrm{K}$ & $\mathrm{P}$ & $\mathrm{S}$ & Mn & $\mathrm{Zn}$ & B \\
\hline & & $(\%)$ & $\begin{array}{c}\mathrm{N} \\
(\%)\end{array}$ & \multicolumn{3}{|c|}{ Meq./100g } & \multicolumn{5}{|c|}{$\mu g / g$} \\
\hline $\mathrm{T}_{1}=\mathrm{Zn}_{0} \mathrm{~B}_{0}$ & 7.0 & 1.22 & 0.070 & 11.1 & 3.2 & 0.09 & 17 & 15 & 6.0 & 0.80 & 0.11 \\
\hline $\mathrm{T}_{2}=\mathrm{Zn}_{0} \mathrm{~B}_{0.5}$ & 7.1 & 1.25 & 0.075 & 11.4 & 3.3 & 0.09 & 18 & 17 & 7.0 & 1.2 & 0.14 \\
\hline $\mathrm{T}_{3}=\mathrm{Zn}_{0} \mathrm{~B}_{1.0}$ & 7.2 & 1.27 & 0.075 & 11.8 & 3.4 & 0.09 & 20 & 17 & 7.5 & 1.3 & 0.15 \\
\hline $\mathrm{T}_{4}=\mathrm{Zn}_{0} \mathrm{~B}_{2.0}$ & 7.3 & 1.30 & 0.077 & 11.9 & 3.3 & 0.07 & 19 & 16 & 8.0 & 0.82 & 0.18 \\
\hline $\mathrm{T}_{5}=\mathrm{Zn}_{0.75} \mathrm{~B}_{0}$ & 7.2 & 1.29 & 0.080 & 11.7 & 3.5 & 0.08 & 20 & 18 & 8.0 & 1.5 & 0.12 \\
\hline $\mathrm{T}_{6}=\mathrm{Zn}_{0.75} \mathrm{~B}_{0.5}$ & 7.4 & 1.31 & 0.085 & 12.0 & 3.2 & 0.09 & 21 & 19 & 8.2 & 1.4 & 0.14 \\
\hline $\mathrm{T}_{7}=\mathrm{Zn}_{0.75} \mathrm{~B}_{1.0}$ & 7.3 & 1.33 & 0.084 & 11.9 & 3.6 & 0.09 & 20 & 18 & 8.0 & 1.5 & 0.25 \\
\hline $\mathrm{T}_{8}=\mathrm{Zn}_{0.75} \mathrm{~B}_{2.0}$ & 7.4 & 1.38 & 0.088 & 12.1 & 3.4 & 0.08 & 21 & 17 & 7.3 & 1.4 & 0.26 \\
\hline $\mathrm{T}_{9}=\mathrm{Zn}_{1.5} \mathrm{~B}_{0}$ & 7.2 & 1.32 & 0.080 & 12.0 & 3.5 & 0.09 & 19 & 18 & 8.4 & 1.6 & 0.12 \\
\hline $\mathrm{T}_{10}=\mathrm{Zn}_{1.5} \mathrm{~B}_{0.5}$ & 7.3 & 1.40 & 0.089 & 12.2 & 3.3 & 0.11 & 21 & 18 & 7.7 & 1.5 & 0.19 \\
\hline $\mathrm{T}_{11}=\mathrm{Zn}_{1.5} \mathrm{~B}_{1.0}$ & 7.3 & 1.55 & 0.096 & 12.3 & 3.6 & 0.12 & 23 & 20 & 8.5 & 1.6 & 0.25 \\
\hline $\mathrm{T}_{12}=\mathrm{Zn}_{1.5} \mathrm{~B}_{2.0}$ & 7.3 & 1.54 & 0.095 & 12.5 & 3.4 & 0.11 & 22 & 19 & 8.0 & 1.7 & 0.29 \\
\hline $\mathrm{T}_{13}=\mathrm{Zn}_{3.0} \mathrm{~B}_{0}$ & 7.3 & 1.50 & 0.093 & 11.9 & 3.4 & 0.11 & 21 & 20 & 8.0 & 1.8 & 0.14 \\
\hline $\mathrm{T}_{14}=\mathrm{Zn}_{3.0} \mathrm{~B}_{0.5}$ & 7.4 & 1.52 & 0.094 & 12.4 & 3.3 & 0.09 & 22 & 18 & 7.9 & 1.9 & 0.18 \\
\hline $\mathrm{T}_{15}=\mathrm{Zn}_{3.0} \mathrm{~B}_{1.0} 0$ & 7.2 & 1.45 & 0.095 & 12.1 & 3.5 & 0.10 & 20 & 19 & 8.0 & 1.8 & 0.23 \\
\hline $\mathrm{T}_{16}=\mathrm{Zn}_{3.0} \mathrm{~B}_{2.0}$ & 7.4 & 1.46 & 0.089 & 12.3 & 3.2 & 0.08 & 21 & 21 & 7.0 & 1.8 & 0.28 \\
\hline Initial level & 7.0 & 1.11 & 0.073 & 11.3 & 3.3 & 0.08 & 17 & 17 & 8 & 0.95 & 0.13 \\
\hline Critical level & - & - & 0.12 & 2.0 & 0.8 & 0.2 & 14 & 14 & 5 & 2 & 0.20 \\
\hline
\end{tabular}

Table 8. Response function of mungbean to $\mathrm{Zn}$ and $\mathrm{B}$ for seed yield at Madaripur.

\begin{tabular}{|c|c|c|c|c|c|c|}
\hline $\begin{array}{l}\text { Regression } \\
\text { equation }\end{array}$ & $\begin{array}{c}\text { Co- } \\
\text { efficient } \\
\text { of } \\
\text { determina } \\
\text { tion } \\
\left(\mathrm{R}^{2}\right)\end{array}$ & $\begin{array}{l}\text { Optim } \\
\text {-um } \\
\text { dose } \\
\text { (kg/ } \\
\text { ha) }\end{array}$ & $\begin{array}{c}\text { Econo- } \\
\text { mic } \\
\text { dose } \\
(\mathrm{kg} / \mathrm{ha})\end{array}$ & $\begin{array}{c}\text { Maxi- } \\
\text { mum } \\
\text { seed yield } \\
\text { (kg/ha) } \\
\text { for } \\
\text { optimum } \\
\text { dose }\end{array}$ & $\begin{array}{l}\text { Production } \\
\text { of } \\
\text { seed ( } \mathrm{kg} / \mathrm{ha} \text { ) } \\
\text { for } 1 \mathrm{~kg} \mathrm{Zn} \\
\text { or B (use } \\
\text { efficiency) }\end{array}$ & $\begin{array}{c}\text { Beyond } \\
\text { optimum dose } \\
\text { the reduction } \\
\text { of seed yield } \\
\text { (kg/ha) for } \\
1 \mathrm{~kg} \\
\text { Zn or B }\end{array}$ \\
\hline \multicolumn{7}{|l|}{$\mathrm{Zn}$} \\
\hline $\begin{array}{l}y=2076+574.7 x \\
-153.82 x^{2}\end{array}$ & 0.9986 & 1.87 & 1.84 & 2613 & 287 & 154 \\
\hline \multicolumn{7}{|l|}{ B } \\
\hline $\begin{array}{l}y=2245.3+ \\
384.35 x-155.09 x^{2}\end{array}$ & 0.9901 & 1.24 & 1.18 & 2483 & 192 & 155 \\
\hline
\end{tabular}

Mungbean = 45 Tk./kg; Zn = 377 Tk./kg; B = 800 Tk./kg. 
A positive and quadratic relationship was also found between seed yield and levels of B (Fig. 2). The optimum dose of B from the quadratic production function was $1.24 \mathrm{~kg} / \mathrm{ha}$ (Table 8). Using the optimum dose, the maximum seed yield $2483 \mathrm{~kg} / \mathrm{ha}$ could be expected for Madaripur area (Table 8). However, the optimum economic dose of B was $1.18 \mathrm{~kg} / \mathrm{ha}$. The use efficiency showed that each $1 \mathrm{~kg} \mathrm{~B}$ could produce $192 \mathrm{~kg} / \mathrm{ha}$ of seed yield upto the optimum level. Above this optimum dose, $1 \mathrm{~kg} / \mathrm{ha}$ excess B if applied then there was a risk of loosing $155 \mathrm{~kg} / \mathrm{ha}$ of seed yield.

\section{Conclusion}

From two years' trial, it may be concluded that the combination of $Z_{1.5} B_{1.0}$ with a blanket dose of $\mathrm{N}_{20} \mathrm{P}_{25} \mathrm{~K}_{35} \mathrm{~S}_{20} \mathrm{~kg} / \mathrm{ha}$ was found suitable for maximizing the yield of mungbean in Calcareous Low Ganges River Floodplain Soil (AEZ-12) at Madaripur region of Bangladesh.

\section{References}

Abdo, F.A. 2001. The response of two mungbean cultivers to zinc, manganese and boron I. Morphological, physiological and anatomical aspects. Bull. Fac. Agric.. Cairo Univ. 52(3): 445-466.

Afzal, M.A., M.A. Bakr, A. Hamid, M.M. Haque and M.S. Aktar, 2004. Mungbean in Bangladesh. Lentil Blackgram and Mungbean Development Pilot Project. Pulses Research Centre, BARI, Gazipur- 1701. 60 pp. Publication No. 23.

Ahlawat I. P. S. and T. K. Srivastava. 1997. Fertility management in pulse based cropping systems. Pages 509-523. In: Recent Advances in Pulses Research (Eds. Asthana AN and Masood Au). Indian Soceity of Pulses Research and Development, IIPR. Kanpur, India.

Anonymous. 2009. 25 Years of Pulses Research at IIPR, 1984-2009 (Eds. Shiv Kumar and Mohan Singh), Published by: Indian Institute of Pulses Research, Kanpur 208024. India.

Anonymous. 2000. Annual Report. Soil Management Collaborative Research Support Project, 1999-2000.

Ashraf, M.H. 2007. Requirement of boron for Mustard-Mungbean-Rice pattern and zinc for Maize-Mungbean-Rice pattern in Calcareous soil. In Ph.D. Dissertation. Department of Soil Science. Bangladesh Agricultural University, Mymensingh.

BARC. 2005. Fertilizer Recommendation Guide. Bangladesh Agricultural Research Council, Farm Gate, Dhaka-1215.

Iqtidar. A. and S. F. Rahman. 1984. Effect of boron on the protein and amino acid composition of wheat grain. J Agric. Sci., UK, 103(1): 75-80.

Islam, M.R., T.M. Riasat and M. Jahiruddin. 1997. Direct and residual effects of S. Zn and B on yield and nutrient uptake in a rice-mustard cropping system. J. Indian Soc. Soil Sci. 45: 126-129. 
Jahiruddin, M., M.S. Haque, A.K.M.M. Haque and P.K. Ray. 1992. Influence of boron. copper and molybdenum on grain formation in wheat. Crop Res. 5: 3 5-42.

Kaisher. M. S., M.T Rahman, M. H. A. Amin, A. S. M. Amanullah and A. S. M. Ahsanullah. 2010. Effects of sulphur and boron on the seed yield and protein content of mungbean. Bangladesh Research Publication Journal 3(4): 1181-1186.

Obata, H., S. Kawamura, K. Senoo and A. Tanaka. 1999. Changes in the level of protein and activity of $\mathrm{Cu} / \mathrm{Zn}$ superoxide dismutase in zinc deficient rice plant, Oryza sativa L. Soil Sci. Plant Nutr 45: 891-896.

Rahman, A., M. Jahiruddin and M.H. Mian. 1993. Response of two mustard varieties to added sulphur and boron in Old Brahmaputra Floodplain Soils. Bangladesh J. Nucl. Agric. 9: 15-28.

Raj, S. 1985. An Introduction to physiology of field crops, Oxford and IBH Publishing Co.. New Delhi. pp.94-97.

Rao J V and R B L. Bhardwaj. 1980. Influence of residual fertility on greengram in intensive cropping system. Indian J. Agron. 25: 97-101.

Robinson, R.G. 1973. Elemental composition and response to nitrogen of sunflower and corn. Agron J. 65: 318-320.

Ryan, J and AMA. El-Moneim. 2007. Implications of Zinc deficiency for ameliorating toxicity (lathyrism) in grasspea. In Conf. Proc.; Zinc Crops 2007: Improving Crop Production and Human Health, Istambul, Turkey.

Sakal, R., A. P. Singh and B. P. Singh.1986. Annual report of all Indian Coordinated Scheme of Micronutrients in Soil and Plants, RAU, Pusa, Bihar, India.

Shorrocks, V,M. 1984. Boron deficiency, its prevention and cure. Borax holdings Ltd.. London.

Verma, R.J. and RH. Mishra. 1999. Effect of doses and methods of boron application on growth and yield of mungbean. Indian J. Pulses Res. 12 (11): 115-118.

Vitosh, M.L., D.D. Wameke and R. E. Lucas. 1997. Boron. Mishigan State University Extension Soil and Management Fertilizer. Available on the http://www.Msue.msu.EDV. 